\title{
Creationism and Evolutionism: A Theological, Scientific and Philosophical Discourse.
}

\author{
Obasola, Kehinde E \\ Department of Religious Studies \\ Olabisi Onabanjo University, Ago Iwoye, Ogun State, Nigeria \\ Shogunle, N. Oluwaseyi \\ Department of Religious Studies \\ Olabisi Onabanjo University, Ago Iwoye, Ogun State, Nigeria
}

\begin{abstract}
The issue of creation and evolution has been a major source of conflict between the Theologians who believe that the universe is the creative ability of God and that this creation is ex-nihilo. The ex-nihilism of the creation has also engendered series of argument among various interests, particularly among the scientists and Philosophers alike. This came as a result of the apparent contradictions observable in creation which calls for attention. It is in this regard that these various groups have arisen to either debunk or refute the creationist principle on the ground of its incoherent and illogical trends which do not ascertain the basic requirements for explaining the rationale behind observable difference in the universe which is believed to have been created by God. Consequently, the scientific and philosophical traditions seem to be disillusioned by the claim of the theologians with regard to creation. Hence, this paper attempts to explore the scientific, the philosophical and theological perspectives of the issue of creation and evolution with the view to ascertaining the veracity of their claims.

Keywords: Creationism, Evolutionism, Theological, Philosophical, Discourse
\end{abstract}

\section{INTRODUCTION}

The creation-evolution controversy (also termed the creation vs. evolution debate or the origins debate) is a recurring theological and cultural-political dispute about the origins of the Earth, humanity, life, and the universe between those who espouse the validity and/or superiority of literal interpretations of creation story, and the proponents of evolution, backed by scientific consensus (Isaac, 2000). The dispute particularly involves the field of evolutionary biology, but also the fields of geology, palaeontology, thermodynamics, nuclear physics and cosmology. Though also present in Europe and elsewhere, and often portrayed as part of the culture wars, this debate is most prevalent in the United States (Andrew, 2009). The debate also focuses on issues such as the definition of science (and of what constitutes scientific research and evidence), science education (and whether the teaching of the scientific consensus view should be 'balanced' by also teaching fringe theories), free speech, separation of Church and State, and theology.

How did human life begin? How did the human race originate? These questions form the bedrock of the debate, which is as ancient as the pyramids or as recent as today's Punch Newspaper. According to Thieme, (1994) many scientists have promoted the hypothesis that life most likely started from molecules that formed DNA - like material which evolved into mankind. Our universe is thought to have begun as an infinitesimally small, infinitely hot, infinitely dense, something - a singularity. Where did it come from? We don't know. Why did it appear? We don't know. After its initial appearance, it apparently inflated (the Big Bang), 
expanded and cooled, going from very, very small and very, very hot, to the size and the temperature of our current universe. It continues to expand and cool to this day and we are inside of it (Herzig and Simcox, 2005). They believed chemical element spontaneously combined to produce a spark. Could life occur from a set of random circumstances where the mathematical probability is nil? Thieme, (1994) however maintained that the complexity and harmony of nature, the incredible precision and sophistication of the human mind and body demand a creator and Designer. Design and order reveal a first cause of life, an intelligence and Will behind the phenomenal process of the creation of all forms of biological life.

No scientist witnessed the creation of the universe or the origin of life. These beginnings lie outside the province of scientific observation and verification. Today's theories can be revised or destroyed by tomorrow's discoveries. Whenever hypothesis and conclusions cannot be verified, science degenerates into the realm of speculation. Scientific conclusions are no more valid than their premises (Isaac, 2000). If we exclude God, then the existence of the universe becomes an unsolvable mystery and our lives become meaningless. The very grandeur of creation displays the majestic glory and attributes of God, (Ps.91:1, Rom. 1:20). God is the creator; only He can accurately answer questions about the beginnings of the universe.

\section{HISTORY OF THE CONTROVERSY}

The creation-evolution controversy originated from Europe and North America in the late eighteenth century when discoveries in geology led to various theories of an ancient earth, and fossils showing past extinctions prompted early ideas of evolution, notably Lamarckism. In England these ideas of continuing change were seen as a threat to the fixed social order, and were harshly repressed. Conditions eased, and in 1844 the controversial Vestiges popularised transmutation of species. The scientific establishment dismissed it scornfully and the Church of England reacted with fury, but many Unitarians, Quakers and Baptists opposed to the privileges of the Established church favoured its ideas of God acting through laws. The publication of Charles Darwin's On the Origin of Species by Means of Natural Selection in 1859 brought scientific credibility to evolution, and made it more respectable.

There was intense interest on the religious implications of Darwin's book, but the Church of England's attention was largely diverted by theological controversy over higher criticism set out in Essays and Reviews by liberal Christian authors, some of whom expressed support for Darwin, as did many nonconformists. The Reverend Charles Kingsley openly supported the idea of God working through evolution. However, many Christians were opposed to the idea and even some of Darwin's close friends and supporters including Charles Lyell and Asa Gray could not accept some of his ideas. Thomas Huxley, who strongly promoted Darwin's ideas while campaigning to end the dominance of science by the clergy, coined the term agnostic to describe his position that God's existence is unknowable, and Darwin also took this position, but evolution was also taken up by prominent atheists including Edward Aveling and Ludwig Büchner and criticised, in the words of one reviewer, as "tantamount to atheism"(Isaac, 2000). By the end of the 19th century, Roman Catholics guided by Pope Leo XIII accepted human evolution from animal ancestors while affirming that the human soul was directly created by God.

Creationists during this period were largely premillennialists, whose belief in Christ's return depended on a quasi-literal reading of the Bible. However, they were not as concerned about geology, freely granting scientists any time they needed before the Garden of Eden to account for scientific observations, such as fossils and geological findings. In the immediate postDarwinian era, few scientists or clerics rejected the antiquity of the earth or the progressive nature of the fossil record. Likewise, few attached geological significance to the Biblical flood, unlike subsequent creationists. Evolutionary sceptics, creationist leaders and sceptical 
scientists were usually willing either to adopt a figurative reading of the first chapter of Genesis, or to allow that the six days of creation were not necessarily 24-hour days.

\section{CREATIONISM: IN THE BEGINNING}

In the beginning \{bereshith, הכלהים , God \{Elohim created \{bara, ברא the heavens and the earth \{hashamayim we'et ha' eretz הארץ השמים ואת Gen.1:1.

God the Holy Spirit succinctly announces the magnificent creation of the universe. Such a brief summary of the origin of the universe demands attention to every word for accurate interpretation. It was not God's intention in Gen.1:1 to provide a detailed account of how the universe came into existence, but merely to reveal sufficient information for mans' understanding of God's power in creation. Exegetically, the Hebrew prepositional phrase bereshith, a combination of the Hebrew preposition be, meaning 'in,' and reshith, meaning 'beginning.' This term literally indicates, 'in the beginning which was not the beginning.' This was the beginning of the universe, but not the beginning of eternal God. [Ps.90:2].

The first phrase in the Gospel of John recalls the creation recorded in Gen.1:1.

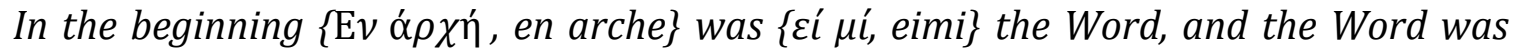
[eimi] with God, and the Word was [eimi] God. John 1:1.

'Was' is a translation of the imperfect active indicative of the verb for existence, eimi, 'to be.' The imperfect tense describes continuous action in past time. The Holy Spirit used this tense in this verse to communicate that the Word, the Lord Jesus Christ, pre-existed the creation of the universe. This thrice - repeated verb emphasizes the undiminished deity of Jesus Christ. Bereshith divides eternity past from the beginning of the universe. Prior to Gen.1:1, no universe existed; there was no matter, no energy, no time, nothing but the triune God and His angels. Verse one breach the barrier of eternity to proclaim the sudden origin of the universe. Six or seven days were not required for God to create the universe. God spoke and the universe instantly came into being (Thieme, 1994).

\section{THE ACTIVITY OF CREATION}

Genesis chapters 1 and 2 contain four Hebrew verbs that depict God's activity of creating the original human life.

1. $\{$ bara, בדא ב means 'to create,' to make something 'from nothing,' ex nihilo in Latin. Bara is found in three verses of Gen.1. Each usage reflects an essential creative act by God: He generated inorganic matter from no previously existing material when He created the heavens and earth (Gen.1:1). And He provided life to animals (Gen.1:21) and humans (Gen.1:27) where no life formerly existed.

2. Although Adam's human life was created from nothing, his body was \{yatsar,יצד 'formed' from dust, an already existing material. This refers to the divine formation of the male body as a biologically living organism. "Then the LORD God formed [yatsar] man [biological life] from the ground". (Gen.2:7a).

Biological life exists in all cells of the body and provides the functions necessary to sustain living material. Biological life is material and does not include a human soul, which is immaterial. Therefore biological life by itself is not human life. By comparison bara describes the life of humanity as a complete and unique creation which never before existed, 'created ... in the image of God.' 
3. \{asah, צשה , used in Gen. 1:26, means 'to make' or manufacture something after a pattern. The pattern God followed in making man was Himself, 'in our image,' betselem בצלמ 'likeness.

\section{DARWIN AND THE EVOLUTION DEBACLE}

Charles Darwin was born February 12, 1809, in Shrewsbury, England. His grandfather, Erasmus Darwin, was an evolutionist/naturalist, poet, and philosopher. His father, Robert, was a successful and wealthy physician. His mother died when he was eight. At one time Darwin considered entering the clergy of the Church of England. That path changed radically after he spent five years (1831-1836) sailing and exploring the variety of living creatures on the Galapagos Island off the coast of Ecuador (Krewson, 2005). In his autobiography, Darwin explained that at that time, he wrestled with the presence of evil in a world created by God:

There seems to me too much misery in the world. I cannot persuade myself that a beneficent and omnipotent God would have designedly created the Ichneumonidae with the express intention of their feeding within the living bodies of caterpillars, or that a cat should play with mice (Herzig, 2005, p. 17)

It is instructive to note that Darwin was introduced to Charles Lyell's work, Principles of Geology, at a critical time when his religious beliefs came into direct conflict with his expanding knowledge of science; he began to doubt the inerrancy of the Scripture:

I had gradually come by this time, [i.e.1836 - 1839] to see that the Old Testament was no more to be trusted than the sacred books of the Hindoos or the beliefs of any Barbarian (Herzig, 2005, p. 18)

During this Beagle expedition, Darwin began to write his theory of evolutionary change and the origin of species by a process of natural selection. It was then he wrote to his friend Joseph Hooker, arguably the most important British botanist of the $19^{\text {th }}$ century, "I am almost convinced... that species are not (it is like confessing a murder) immutable." Many say the "murder" was the murder of God (Herzig, 2005, p. 19). Herzig, while quoting Russell Grigg, said Darwin's son, Francis, 'recalled him saying, 'I never gave up Christianity until I was forty years of age.' Grigg continued, 'and the death of his eldest daughter Annie from fever at this period of his life hammered the final nail in the coffin of his Christianity (Brentnall and Grigg, 2002). In a letter written in 1880 Darwin stated, "I am sorry to have to inform you that I do not belief in the Bible as a divine revelation, and therefore not in Jesus Christ as the son of God" (Herzig, 2005, p. 19). In 1871, his book, Descent of Man was published. There he argued that humans are no different from other forms of life and that we, too, evolved through natural selection.

\section{EVOLUTION THEOLOGY}

Evolution teaches that the physical universe evolved from nothing at all by a kind of quantum leap from nothing into an infinitesimal particle of space - time. This primeval particle rapidly inflated and then exploded into the so - called Big Bang. From this the universe has been rapidly expanding ever since, somehow enabling stars and galaxies to form, then planets. On this earth planet, and perhaps others, non-living chemicals $\mathrm{i} n$ the primeval seas somehow came to life as primitive reproducing cells. These developed into multicelled marine invertebrates, then into fish. Some of this fish became amphibian, and then turned into reptiles. One or more of the latter evolved into bird, while other reptiles were evolving into mammals. Finally, one mammalian line developed into primates, and some ape - like creature in this line became man. Thus, Darwin disclosed his god. In a letter to a friend he even named it and 
capitalized it: "my deity [is] 'Natural Selection". As an old man in ill health, he wrote: ...I do not believe that there ever has been any revelation. As for a future life, every man must judge for himself between conflicting vague probabilities (Morris, 2002).The path that Darwin travelled is described in Romans 1:21 -23:

Although they knew God, they did not glorify Him as God, nor were thankful, but became futile in their thoughts, and there foolish heart was darkened. Professing to be wise, they became fools, and changed the glory of the incorruptible God into an image made like corruptible man - and birds and four - footed animals and creeping things.

\section{CREATION SCIENCE}

As biologists grew more and more confident in evolution as the central defining principle of biology, American membership in churches favouring increasingly literal interpretations of scripture rose, with the Southern Baptist Convention and Lutheran Church - Missouri Synod outpacing all other denominations. With growth, these churches became better equipped to promulgate a creationist message, with their own colleges, schools, publishing houses, and broadcast media.

In 1961, the first major modern creationist book was published: Henry M. Morris and John C. Whitcomb's The Genesis Flood. Morris and Whitcomb argued that creation was literally 6 days long, that humans lived concurrently with dinosaurs, and that God created each 'kind' of life individually. On the strength of this, Morris became a popular speaker, spreading antievolutionary ideas at fundamentalist churches, colleges, and conferences. Morris' Creation Science Research Centre (CSRC) rushed publication of biology text books that promoted creationism, and also published other books such as Kelly Segrave's sensational Sons of God Return that dealt with UFOlogy, flood geology, and demonology against Morris' objections. Ultimately, the CSRC broke up over a divide between sensationalism and a more intellectual approach, and Morris founded the Institute for Creation Research, which was promised to be controlled and operated by scientists. During this time, Morris and others who supported flood geology adopted the terms scientific creationism and creation science. The flood geologists effectively co-opted "the generic creationist label for their hyper literalist views"(Brentnall and Grigg, 2002).

\section{CONTROVERSY IN RECENT TIMES}

The controversy continues to this day, with the mainstream scientific consensus on the origins and evolution of life challenged by creationist organizations and religious groups who desire to uphold some form of creationism --usually young earth creationism, creation science, old earth creationism or intelligent design--as an alternative (some of these group shall be discussed later). Most of these groups are explicitly Christians, and more than one sees the debate as part of the Christian mandate to evangelize. Some see science and religion as being diametrically opposed views which cannot be reconciled. More accommodating viewpoints, held by many mainstream churches and many scientists, consider science and religion to be separate categories of thought, which ask fundamentally different questions about reality and posit different avenues for investigating it. Public opinion in regards to the concepts of evolution, creationism, and intelligent design is fluctuating.

\section{THE CREATION/EVOLUTION CONTINUUM IN CHRISTIAN CREATIONISM}

As mentioned earlier, Creationism is not without its own hiccups, several groups have arisen to champion the cause of evolution. This of course is not without individual colourations and sometimes outright ridiculousness. They are as follows: 


\section{Flat Earthers}

Flat Earthers believe that the earth is flat and is covered by a solid dome or firmament. Waters above the firmament were the source of Noah's flood. This belief is based on a literal reading of the Bible, such as references to the "four corners of the earth" and the "circle of the earth." Few people hold this extreme view, but some do.

\section{Geocentrism}

Geocentrists accept a spherical earth but deny that the sun is the canter of the solar system or that the earth moves. As with flat-earth views; the water of Noah's flood came from above a solid firmament. The basis for their belief is a literal reading of the Bible. "It is not an interpretation at all; it is what the words say."

\section{Young-Earth Creationism}

Young Earth Creationists (YEC) claims a literal interpretation of the Bible as a basis for their beliefs. They believe that the earth is 6000 to 10,000 years old, that all life was created in six literal days, that death and decay came as a result of Adam \& Eve's fall, and that geology must be interpreted in terms of Noah's Flood. However, they accept a spherical earth and heliocentric solar system. Young-Earth Creationists popularized the modern movement of scientific creationism by taking the ideas of George McCready Price, a Seventh Day Adventist, and publishing them in The Genesis Flood (Whitcomb \& Morris, 1961). Young Earth Creationists (YEC) is probably the most influential brand of creationism today.

\section{Omphalos}

The Omphalos argument, first expounded in a book of that name by Philip Henry Gosse (1857), argues that the universe was created young but with the appearance of age, indeed that an appearance of age is necessary. This position appears in some contemporary young earth creationist writing. For example, Whitcomb \& Morris (1961: 232) argue that earth's original soils were created appearing old. The position is sometimes satirized by suggesting that the universe was created last week with only an appearance of older history.

\section{Old Earth Creationism}

Old-Earth Creationists accept the evidence for an ancient earth but still believe that life was specially created by God, and they still base their beliefs on the Bible. There are a few different ways of accommodating their religion with science.

\section{Gap Creationism (also known as Restitution Creationism)}

This view says that there was a long temporal gap between Genesis 1:1 and Genesis 1:2, with God recreating the world in 6 days after the gap. This allows both an ancient earth and a Biblical special creation.

\section{Day-Age Creationism}

Day-age creationists interpret each day of creation as a long period of time, even thousands or millions of years. They see a parallel between the order of events presented in Genesis 1 and the order accepted by mainstream science. Day-Age Creationism was more popular than Gap Creationism in the 19th and early 20th centuries.

\section{Progressive Creationism}

Progressive Creationism is the most common Old-Earth Creationism view today. It accepts most of modern physical science, even viewing the Big Bang as evidence of the creative power of God, but rejects much of modern biology. Progressive Creationists generally believe that God 
created "kinds" of organisms sequentially, in the order seen in the fossil record, but say that the newer kinds are specially created, not genetically related to older kinds.

\section{Intelligent Design Creationism}

Intelligent Design Creationism descended from Paley's argument that God's design could be seen in life (Paley, 1803). Modern IDC still makes appeals to the complexity of life and so varies little from the substance of Paley's argument, but the arguments have become far more technical, delving into microbiology and mathematical logic. In large part, Intelligent Design Creationism is used today as an umbrella anti-evolution position under which creationists of all flavours may unite in an attack on scientific methodology in general. A common tenet of IDC is that all beliefs about evolution equate to philosophical materialism.

\section{Evolutionary Creationism}

Evolutionary Creationism differs from Theistic Evolution only in its theology, not in its science. It says that God operates not in the gaps, but that nature has no existence independent of His will. It allows interpretations consistent with both a literal Genesis and objective science, allowing, for example, that the events of creation occurred, but not in time as we know it, and that Adam was not the first biological human but the first spiritually aware one.

\section{Theistic Evolution}

Theistic Evolution says that God creates through evolution. Theistic Evolutionists vary in beliefs about how much God intervenes in the process. It accepts most or all of modern science, but it invokes God for some things outside the realm of science, such as the creation of the human soul. This position is promoted by the Pope and taught at mainline Protestant seminaries.

\section{Methodological/ Materialistic Evolution}

Materialistic Evolution differs from Theistic Evolution in saying that God does not actively interfere with evolution. It is not necessarily atheistic, though; many Materialistic Evolutionists believe that God created evolution, for example. Materialistic evolution may be divided into methodological and philosophical materialism. Methodological materialism limits itself to describing the natural world with natural causes; it says nothing at all about the supernatural, neither affirming nor denying its existence or its role in life.

\section{Philosophical Materialistic Evolution}

Philosophical materialism says that the supernatural does not exist. It says that not only is evolution a natural process, but so is everything else.

\section{Non-Christian Creationism}

There are some positions on origins which don't fit cleanly in the continuum given above. Nor are they based on religion (although the Raelian position is the basis for a religion). They have little influence, but they are worth noting as illustrations of the variety of beliefs which people hold.

- The Raelians believe that life was created by scientists from another planet. The scientists continue to visit earth and were mistaken for gods.

- Panspermia is the position that primitive life, in the form of bacteria or other microbes, was carried to earth from other star systems. Other life evolved from there.

- Catastrophic Evolution: This position says that evolution occurred suddenly, driven by extreme, planet-wide catastrophes. 


\section{Arguments against Evolution}

- Methods of dating the earth are inaccurate.

- Radioactive dating can't be calibrated.

- Receding moon would have been touching earth.

- All comets would have disintegrated after 10,000 years.

- 3000 years was time enough for all languages, religions to develop.

- The animals couldn't have distributed themselves all over the globe.

\section{Chaos and Complexity}

- Life is too complex to have happened by chance.

- Complexity from simplicity

- Evolution violates the 2nd law of thermodynamics.

- The creation of matter or energy is not now taking place

- Various conceivable patterns fail to emerge

- The fundamental principle of evolution contradictory to established laws

- We have never seen any natural processes which result in a complexity increase.

- The great complexity of nature shows it was designed.

- There is no evidence of biological life anywhere else in the universe

- Odds too great

\section{WHAT DARWIN DID NOT KNOW}

If Darwin could have foreseen coming scientific developments, he would have had good reason to be concerned that his theory might one day be proved wrong. In particular, Gregory Mendel had not yet established and published his work on the laws of heredity and genetics, which said that the characteristics of offspring are passed on from parents according to precise mathematical ratios and do not derive from chance random processes in what Darwin called "blending inheritance."

James Joules, R.J.E. Clasius and Lord Kelvin were only just developing the concepts of thermodynamics, the first law of which states that energy can neither be created nor destroyed (so the present universe could not have created itself), and the second law of which says that the universe is proceeding in a downward degenerating direction of increasing disorganisation (so things overall do not of themselves become more organized with time).

Louis Pasteur was just beginning his famous experiments, which showed that life (even microbial life) comes from life, not from non - life. The mathematical laws of probability, which show that the odds of life's occurring by chance are effectively zero, had not yet been applied to the theory of evolution. The fossil record had not yet been investigated sufficiently for palaeontologists to be able to say, as they now do, that chains of intermediate 'links' do not exist (Grigg, 2003).

\section{THE FOSSIL RECORD: NO SIGN OF INTERMEDIATE FORMS}

The clearest evidence that the scenario suggested by the theory of evolution did not take place is the fossil record. According to the theory every living species has sprung from a predecessor, a previously existing species turned into something else in time and all species have come into being in this way. Had this been the case, then numerous intermediary species should have existed and lived within this long transformation period (Yahya, 1976).

For instance, some half - fish / half - reptiles should have lived in the past which had acquired some reptilian traits in addition to the fish traits they already had. Or there should have existed some reptile birds, which acquired some bird traits in addition to the reptilian traits they 
already had. Since these would be in a transitional phase, they should be disabled, defective, crippled living beings. Evolutionists refer to these imaginary creatures, which they believe to have lived in the past, as "transitional forms"

If such animals had really existed, there should be millions and even billions of them in number and variety. More importantly the remains of these strange creatures should be present in the fossil record. In The Origin of Species, as quoted by Herzig \& Simcox, (2005) Darwin explained:

\section{If my theory be true, numberless immediate varieties, linking most closely all of the species of the same group together must assuredly have existed ... Consequently, evidence of their former existence would be found only amongst fossil remains}

However, although evolutionists have been making strenuous efforts to find fossils since the middle of the $19^{\text {th }}$ century all over the world, no transitional forms have yet been uncovered. All the fossils unearthed in excavations showed that, contrary to the expectations of evolutionists, life appeared on earth all of a sudden and fully - formed. A famous British palaeontologist, Derek V. Ager, admits this fact, even though he is an evolutionist:

The point emerges that if we examine the fossil record in details, whether at the level of order or species, we find - over and over again - not gradual evolution, but the sudden explosion of one group at the expense of another.(Yahya, 1976).

This means that in the fossil record, all living species suddenly emerge as fully formed, without any intermediate forms in between. This is just the opposite of Darwin's assumptions. Also, it is very strong evidence that living beings are created. The only explanation of a living species emerging suddenly and complete in every detail without any evolutionary ancestor can be that this species was created. This fact is admitted also by the widely known evolutionist biologist, Douglas Futuymas:

Creation and evolution, between them, exhaust the possible explanations for the origin of living things. Organisms either appeared on the earth fully developed or they did not. If they did not, they must have developed from pre - existing species by some process of modification. If they did appear in a fully developed state, they must indeed have been created by some omnipotent intelligence (Yahya, 1976, p. 133).

Fossils show that living beings emerged fully developed and in a perfect state on the earth. That means that 'the origin of species' is, contrary to Darwin's supposition, not evolution but creation. 


\section{CONCLUSION}

The information we have presented so far shows us that the theory of evolution is a claim evidently at variance with scientific findings. There is no better way to conclude than to look at the Holy Scripture, and Job 38:4 - 40:2 succinctly concludes it all:

38:4 Where wast thou when I laid the foundations of the earth? Declare, if thou hast understanding. 5 Who hath laid the measures thereof, if thou knowest? Or who hath stretched the line upon it? 6 Whereupon are the foundations thereof fastened? Or who laid the corner stone thereof; 7 When the morning stars sang together, and all the sons of God shouted for joy? 8 Or who shut up the sea with doors, when it brake forth, as if it had issued out of the womb? 40:2 Shall he that contendeth with the Almighty instruct him? He that reproveth God let him answer it.

\section{References}

Andrew, C. (2009). “Creationist Belief Persist in Europe.” Science 323 (5918): 1159

Botterweck, G. J. (1974- ). Theological Dictionary of the Old Testament. Grand Rapids: Eerdmans.

Brentnall, J. M. and Grigg, R.M. (2002). "Was Darwin a Christian? Did he believe in God? Did he recant evolutionism when he died?" Retrieved from http://chrristiananswers.net/q-aig/Darwin.html

Brown, C. (1986). The New International Dictionary of New Testament Theology. rev. ed.

4 vols. Exeter, Devon, U.K.: Paternoster Press.

Brown, F. Driver, S.R. and Briggs, C. (1996). The Brown, Driver, and Briggs Hebrew and English Lexicon. Peabody, Mass.: Hendrickson.

Herzig,S. (2011). Creation and Evolution Debate. Retrieved from http://www.lucidcafe.com/lucidcafe/library/96feb/darwin.html

Herzig, S. \& Simcox, L. (July / August 2005). Creation vs. Evolution: The Battle for Truth. Israel my Glory Magazine (IMG).

Holladay, William (1978). A Concise Hebrew and Aramaic Lexicon of the Old Testament. Grand Rapids: Eerdmans. Isaac, M. (2006). An Index to Creationist Claims, Retrieved from http://www. /Talk origins Archive.

Isaac, M. (2010). What is Creationism? Retrieved from http://www.wikipaedia/ creationism and evolution. Jenni, E. (1997). Theological Lexicon of the Old Testament. 3 vols. Peabody: Hendrickson Publishers.

Kohlenberger, John R. (1987). Ed. The Interlinear NIV Hebrew-English Old Testament. Grand Rapids: Regency Reference Library, 1987.

Krewson, W. L. (July / August 2005). Creation vs. Evolution: The Battle for Truth. Israel my Glory Magazine (IMG). McGrath, A. (1993). (ed.), Blackwell Encyclopedia of Modern Christian Thought. B. H. Blackwell.

Morris, H. M. (July / August 2005). The Truth about Creation. Israel my Glory Magazine (IMG).

Theological Wordbook of the Old Testament (1980) 2 vols. Chicago: Moody Press.

Thieme, R.B. (1994). The Origin of Human Life. Houston, Texas: R.B. Thieme, Jr., Bible Ministries.

VanGemeren, W. A. (1997). New International Dictionary of Old Testament Theology \& Exegesis. 5 vols. Grand Rapids: Zondervan.

Yahya, H. (1976). “The Nature of the Fossil Record," Proceedings of the British Geological Association, vol. 87, 1976, p.133 